IRSH 50 (2005), Supplement, pp. 25-4I DOI: I0.10I7/S002085900500205 I

(C) 2005 Internationaal Instituut voor Sociale Geschiedenis

\title{
Marriage Choices in a Plantation Society: Bahia, Brazil*
}

\author{
KATHERINE HOLT
}

Summary: This article examines the evolving significance of formal marriage and of partner selection in nineteenth-century Santiago do Iguape Brazil. Across social divides, racial and class endogamy were the norm for marriage partners, but consensual unions were far more likely to unite couples of different races. The information about enslaved couples was more sporadic, but I found that most slaves married partners who shared their country of origin, and that there was a higher slave-marriage rate on larger plantations. My research suggests that free and enslaved people constantly violated the borders separating them within a stratified plantation society, but that formal marriage retained a special significance and was reserved for unions between social equals.

The exigencies of export production dominated every aspect of daily life on the sugar plantations of Santiago do Iguape, Bahia. Located along the large bay surrounding the provincial capital of Salvador in northeastern Brazil, the parish combined the ideal climatic and soil conditions for sugar production, which had provided its primary economic activity for nearly three centuries. Nearly every household owed its livelihood to sugar, from the powerful mill owners at the pinnacle (HISCLASS $\mathrm{I}+2$ ), the overseers and clerks who managed sugar production (HISCLASS $3+4+5$ ), the free skilled workers who transformed cane juice into refined sugar (HISCLASS $6+7$ ), the smaller cane growers dependent on mill owners to process their crops (HISCLASS 8), to the households headed by lessskilled workers and subsistence farmers (HISCLASS 9, IO+ I 2, and I I). As Table I demonstrates, Iguape was a highly stratified society. At the base of the region's wealth were the enslaved majority who performed the arduous physical labor of clearing the fields, planting sugar cane, weeding, cutting,

\footnotetext{
* I would like to thank Professor Jeremy Adelman as well as the staff of Arquivo Público do Estado da Bahia (APEB) and the Family History Center of Princeton. My research was supported by the Fellowship of Woodrow Wilson Scholars at Princeton University and a Fulbright-Hays Grant from the US Department of Education.
} 
Table I. Head of Household HISCLASS Distribution, Santiago do Iguape, Babia 1835

\begin{tabular}{llrr}
\hline & HISCLASS & $\mathrm{N}$ & $\%$ \\
\hline $1+2$ & Higher managers and professionals & 25 & 2.6 \\
$3+4+5$ & Lower managers and professionals, clerical \& sales & 74 & 7.7 \\
$6+7$ & Skilled workers & 98 & 10.2 \\
8 & Farmers and fishermen & 83 & 8.7 \\
9 & Lower skilled workers & 227 & 23.7 \\
11 & Unskilled workers & 118 & 12.3 \\
$10+12$ & Farm workers & 334 & 34.8 \\
& Total & 959 & 100.0 \\
\hline
\end{tabular}

Source: "Relação do Numero de fogos, e moradores no Districto da Freguezia de Sant Iago Maior de Iguape[...]I835", Arquivo Público do Estado da Bahia (APEB), Sec. Colonial e Provincial, maço 6I75-I. Occupations coded according to M.H.D. van Leeuwen and I. Maas, HISCLASS. Paper presented at the 5 th European Social Science History Conference (Berlin, 24-27 March 2004) and I. Maas and M.H.D. van Leeuwen, "SPSS Recode Job from HISCO into HISCLASS", May 2004.

Note: Heads of households were always free or freed.

and bundling the ripe cane at harvest, and the dangerous task of feeding it through the mill's powerful rollers. ${ }^{\text {' }}$

Throughout the Atlantic world, sugar plantations were notorious for their high human toll. A constant stream of African slave imports provided most of the labor for Iguape's sugar growth and processing. In i 835, 54 per cent of Iguape's population was enslaved, and most of these slaves had been born in Africa. Of the remaining population, 8 per cent was branco (of European descent), 27 per cent pardo (combined African/European), and I I per cent preto (of African descent). Slavery remained the predominant form of labor on Iguape's sugar plantations until its abolition in I888. Slavery was widespread, and its influences permeated all other social relationships.

Despite the rigid racial and class hierarchies that typified plantation life, free people of color were the largest population group in Iguape by i 872 , suggesting that even within such a stratified slave society, social norms regulating partner selection did not always hold. Iguape's position as such a quintessentially Brazilian plantation society makes it a valuable case study.

I. On the region's economic and social base, see Stuart Schwartz, Sugar Plantations in the Formation of Brazilian Society: Babia, I550-I835 (New York, I985), B.J. Barickman, A Babian Counterpoint: Sugar, Tobacco, Cassava, and Slavery in the Reconcavo, 1780-I860 (Stanford, CA, I998); and Arlene Díaz and Jeff Stewart, "Occupational Class and Female-Headed Households in Santiago Maior do Iguape, Brazil, I 83 5", Journal of Family History, I6 (I 99 I), pp. 299-3 I3. 
This article examines how Bahians across color, class, and legal divides selected their marital and sexual partners, and traces the evolving significance of formal marriage during the nineteenth century. Notwithstanding the high value placed on legitimacy within nineteenth-century accounts, and a subsequent historiographical emphasis on the patriarchal family as the model for all other households, recent studies reveal a diverse array of family types and ensuing domestic arrangements in nineteenthcentury Brazil. ${ }^{2}$ Households, even in plantation regions, were both smaller and less complex than previously assumed. ${ }^{3}$ However, to some extent this research has focused on the outcome rather than the process of family formation. More investigation is needed of individual strategies in partner selection and family formation, and especially how local economic and demographic structures shaped norms surrounding partner selection. A closer examination of partner selection in Iguape both emphasizes the diversity present in slave societies within Brazil, and the links between Iguape and other Atlantic slave societies dominated by plantation production.

I use three sets of sources for this study. The first is the manuscript census compiled for Santiago do Iguape parish in I 835 . Household by household, this census listed the name, race, age, marital status, and occupation of each inhabitant, along with a description of their relationship to the household head. Enslaved and free dependents were included as part of their master's household - even in the cases of large plantations with hundreds of slaves - reflecting their subservient place within local society. The living arrangements recorded by census takers reveal tangible clues of how individuals in a slave society organized their domestic relationships. The demographic information from the 1835 census is complimented by the aggregate data from the less detailed I 872 national census.

Iguape's parish records provide a second source of quantitative information about partner selection during the nineteenth century. Local parish priests routinely recorded the names, parentage, and legitimacy of birth for prospective spouses, as well as the owners of enslaved partners; information on their ages, occupations, and races was recorded far more

2. Eni de Mesquita Samara, A família brasileira (São Paulo, I983); Dain Borges, The Family in Babia, Brazil, I870-1945 (Stanford, CA, I992); Mariza Corrêa, "Repensando a família patriarcal brasileira", Cadernos de Pesquisa, 37 (198I), pp. 5-I6; Elizabeth Anne Kuznesof, "Sexual Politics, Race, and Bastard-Bearing in Nineteenth-Century Brazil: A Question of Culture or Power?", Journal of Family History, I6 (1991), pp. 24 I-260; Donald Ramos, "Single and Married Women in Vila Rica, Brazil, I754-1838”, Journal of Family History, I6 (1991), pp. $26 \mathrm{I}-282$.

3. B.J. Barickman, "Revisiting the Casa-Grande: Plantation and Cane Farming Households in Early Nineteenth-Century Bahia”, Hispanic American Historical Review, 84 (2004), pp. 61966r. 


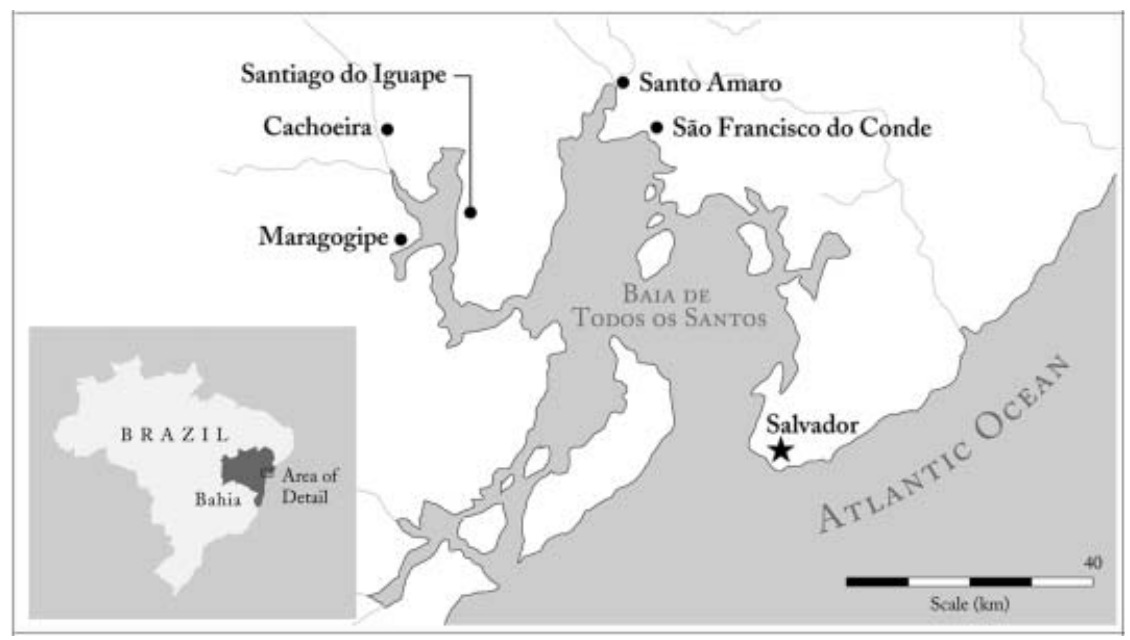

Figure I. Bahia: principal nineteenth-century recôncavo population centers.

sporadically, making longitudinal analysis of these factors difficult. These records only record formal Catholic marriages rather than consensual unions. These quantitative sources are supplemented by written accounts from travelers, advice manuals, and journals. Such written sources privilege the experiences of elites, but still provide important insight into the discourse surrounding marriage and sexual partnerships.

My research suggests that although the formal marriages contracted between elites on the sugar plantations presented a highly visible example of domestic organization aspired to by many members of the middle and lower classes, the influence of this patriarchal model was not absolute. ${ }^{4}$ Consensual unions - couples living together without being legally married - provided a widespread and widely tolerated alternative to formal marriage, even within the fervently Catholic culture. Households consisting of unmarried women and their children were also quite common. Especially among farm laborers, artisans, and slaves, affective ties and family formation rarely required official sanction. Even the sons of plantation owners frequently founded consensual families before, and sometimes alongside, their legitimate households. Conversely, numerous enslaved couples fought to have their unions legitimized by the church,

4. I define patriarchy as a hierarchal relationship of power that privileges masculinity and age. It is not limited to men, as women can borrow its privileges and act patriarchally, but it implies an assumption of masculine prerogatives and activities. The exercise of this type of power often involves the formulation of a large household with a married man presiding over children, agregados, and slaves, but my use of "patriarchal" as a relationship of power does not mean that all who acted patriarchally necessarily lived in households of this type. 
suggesting that even members of the most marginalized social groups saw a concrete value in legal marriage. It is important to uncover how individuals from different social, racial, and economic groups weighed these considerations in deciding whether formally to marry, and how to select a partner.

\section{PARTNER SELECTION IN I 835 SANTIAGO DO IGUAPE}

"When two individuals of different sexes agree to live together, they can not do this, my Cora, except by a solemn contract that gives each party reciprocal rights and duties." 5 In this I 849 letter to his daughter Cora, Bahian statesman José Linho Coutinho placed great emphasis on legitimate - that is, church-sanctified - marriage as the primary bond uniting men and women in nineteenth-century Bahia. Officially sanctioned Catholic unions were the only legally recognized form of marriage in Brazil until the creation of civil marriage in I 890. Catholic marriage was the vehicle for producing legitimate heirs, and its contract the basis for elite social and economic continuity within Bahia's traditional plantation society. Formal marriage also conveyed social prestige, emphasizing a family's stability and respectability within the community.

Weighing against the social benefits of legitimate marriage were considerable economic costs. Fulfilling the ecclesiastical requirements for legal marriages could be quite cumbersome - posting the banns in each parish where the couple had resided, compiling genealogies - as well as expensive. Even more trouble resulted for couples who required religious dispensations to marry. Marriage between cousins, in-laws, couples suspected of prior sexual intimacy, or even those linked by the bonds of spiritual kinship as godparents required costly appeals to dissolve their impediments. In the face of such obstacles, it was no wonder that so many couples eschewed formal marriage. ${ }^{6}$ The considerable percentage (I I.4 per cent) of Iguape marriages that took place despite the economic burden of ecclesiastical dispensations reflected the higher economic status of most free couples who contracted formal marriage. ${ }^{7}$

Ironically, despite his laudatory view of marriage, José Linho Coutinho himself never married Cora's mother. Instead, after the couple's informal

5. José Lino Coutinho, Cartas sobre a educação de Cora (Salvador, I849), Carta XXX, p. 107. 6. Linda Lewin's exhaustive study of Brazilian marriage and inheritance law argues that "by declining to facilitate access to the sacrament of matrimony, through simplified procedures and lower fees, the church insured that mancebia [consensual unions] would thrive"; Lewin, Surprise Heirs (Stanford, CA, 2003): vol. 2, p. 87.

7. A survey of all marriages recorded at five-year intervals found that 7.5 per cent of free marriages required dispensations for consanguinity and 3.9 per cent for "illicit affinity"; Family History Center, Princeton (FHC), Livros de matrimonios, Santiago do Iguape, 1774-1805; I $806-1857 ;$ I $857-1902$. 
relationship ended, Coutinho married another elite woman and started a second, legitimate family. This type of successive family formation was fairly common among elite men in nineteenth-century Brazil. Brazilian law allowed recognized "natural" children, conceived by parents with no impediments to their marriage, to inherit alongside any successive legitimate half-siblings; legislative reform in I 847 restricted these children's rights somewhat by requiring that they be notarily recognized before either of their parents married in order to inherit. Natural children could also be legitimized by their parents' subsequent marriage. Consensual unions represented greater flexibility for men than formal marriage which - even in the rare case of divorce - was dissoluble only by death. ${ }^{8}$

In contrast, formal marriage to another partner was rarely an option for women who formed consensual unions. Virginity formed an essential component of female honor, and in most cases a prerequisite for marriage. To this end, unmarried elite daughters were strictly guarded within their parents' homes. European travelers frequently commented on the degree of isolation of elite Brazilian women: writing in 1846 , George Gardner commented that "I have lived for a week at a time in houses where I was well aware there were ladies, without ever seeing more of them than their dark eyes peering through chinks about the doors of the inner apartments." $"$ By the end of the century, however, the norms surrounding the socialization of elite women underwent a dramatic shift. Carefully chaperoned family gatherings became a venue where young women could talk, dance, and flirt with men who met with their parents' approval. However, most of Iguape's elites still regarded female virginity as a requirement for formal marriage.

Two main exceptions existed to the emphasis on female virginity for brides. The first came in the cases of long-time consensual couples who formalized their relationships in a deathbed marriage. For example, Manoel Paulo dos Santos married Eusebia Maria as she lay dying in I 845 "to benefit her soul"; the couple had lived together for years, but the religious benefits of church marriage only became overwhelming when faced with the possibility of her eternal damnation. ${ }^{10}$ The other exceptions were women of color whose elite lovers provided them with dowries upon dissolving the relationship. Traveler Henry Koster wrote that this capital allowed such women to marry a man "of her own rank, who regards her rather as a widow than as one whose conduct has been incorrect". ${ }^{\text {I }}$ These

8. Linda Lewin, "Natural and Spurious Children in Brazilian Inheritance Law from Colony to Empire: A Methodological Essay", Americas, 48 (1992), pp. 35 I-396.

9. George Gardener, Travels in the Interior of Brazil (New York, I970 [1846]), p. I4.

I0. Marriage of Manoel Paulo dos Santos and Eusebia Maria (27 September I 845), FHC, Livros de matrimonios, Santiago do Iguape, I806-1847, p. I64.

I I. Henry Koster, Travels in Brazil (Carbondale, IL, I966 [1817]), p. I75. 
Table 2. Marital status of free and enslaved adults by race and sex, Santiago do Iguape, Babia I835

\begin{tabular}{|c|c|c|c|c|c|c|c|c|}
\hline & \multicolumn{4}{|c|}{ Men } & \multicolumn{4}{|c|}{ Women } \\
\hline & \multicolumn{2}{|c|}{ Ever married } & \multicolumn{2}{|c|}{ Single } & \multicolumn{2}{|c|}{ Ever married } & \multicolumn{2}{|c|}{ Single } \\
\hline & $\mathrm{N}$ & $\%$ & $\mathrm{~N}$ & $\%$ & $\mathrm{~N}$ & $\%$ & $\mathrm{~N}$ & $\%$ \\
\hline Free branco & 106 & 50.0 & 106 & 50.0 & 102 & 51.8 & 95 & 48.2 \\
\hline Free/freed pardo & 256 & 48.6 & 271 & 51.4 & 276 & 45.5 & 330 & 54.5 \\
\hline Enslaved pardo & 2 & 3.4 & 56 & 96.6 & 1 & 1.9 & 52 & 98.1 \\
\hline Free/freed preto & 76 & 33.6 & 150 & 66.4 & 107 & 33.9 & 209 & 66.1 \\
\hline Enslaved preto & 103 & 5.7 & 1720 & 94.3 & 86 & 8.0 & 991 & 92.0 \\
\hline Total fr & 438 & 45.4 & 527 & 54.6 & 485 & 43.3 & 634 & 56.7 \\
\hline Total enslaved & 105 & 5.6 & 1776 & 94.4 & 87 & 7.7 & 1043 & 92.3 \\
\hline
\end{tabular}

Source: See Table I.

Note: Adult is defined as age sixteen or older to facilitate comparisons with the 1872 census. Ever-married totals include currently married as well as widowed individuals. Branco referred to individuals of European descent, preto to those of African descent, and pardo to those whose color suggested European and African parentage.

exceptions emphasized that in nineteenth-century Brazil both the decision to marry formally and the selection of a suitable partner depended on a careful calculation of the religious, economic, and social costs and benefits. Marriage was neither the only nor even always the most popular alternative for Iguape's couples.

The pictures of domestic arrangements that emerge from the 1835 Iguape parish census provide further evidence for the widespread coexistence of legal and natural unions. Iguape's parish priest preserved an unusually detailed account of the legal and affective ties that bound parish households together. The census enumerates legitimate families headed by married couples, families consisting of male household heads listed with single female "domestics" and their natural children, as well as single mothers heading independent households.

The information recorded about marital status was immediately striking: as Table 2 demonstrates, in I 835 the majority of Iguape's adults had never married. Even when the enslaved population was omitted, only 45.4 per cent of adult men and 43.3 per cent of adult women were married or widowed. In the sixteenth and seventeenth centuries, the scarcity of elite women contributed to a low formal marriage rate in Bahia; however by I835 the free sex ratio was 9I, meaning that free women slightly outnumbered free men. The low rate of formal marriage could thus no longer be ascribed to a dearth of branca women. The census suggests a link between an individual's decision to contract formal marriage and their ascribed social status; confined by their African ancestry to the bottom of 
Table 3. Marital status of Santiago do Iguape household heads by HISCLASS, I835

\begin{tabular}{|c|c|c|c|c|c|c|c|c|c|}
\hline \multirow[t]{3}{*}{ HISCLASS } & \multicolumn{9}{|c|}{ Household head's marital status } \\
\hline & \multicolumn{2}{|c|}{ Ever married } & \multicolumn{2}{|c|}{ Never married } & \multicolumn{2}{|c|}{$\begin{array}{c}\text { Consensual } \\
\text { union }\end{array}$} & \multicolumn{2}{|c|}{ Single parent } & \multirow{2}{*}{$\frac{\text { Total }}{\mathrm{N}}$} \\
\hline & $\mathrm{N}$ & $\%$ & $\mathrm{~N}$ & $\%$ & $\mathrm{~N}$ & $\%$ & $\mathrm{~N}$ & $\%$ & \\
\hline $1+2$ & 18 & 72.0 & 4 & 16.0 & 3 & 12.0 & 0 & 0.0 & 25 \\
\hline $3+4+5$ & 42 & 56.8 & 22 & 29.7 & 7 & 9.5 & 3 & 4.1 & 74 \\
\hline $6+7$ & 58 & 59.2 & 26 & 26.5 & 12 & 12.2 & 2 & 2.0 & 98 \\
\hline 8 & 53 & 63.9 & 19 & 22.9 & 8 & 9.6 & 3 & 3.6 & 83 \\
\hline 9 & 72 & 31.7 & 75 & 33.0 & 6 & 2.6 & 74 & 32.6 & 227 \\
\hline 11 & 54 & 45.8 & 46 & 39.0 & 5 & 4.2 & 13 & 11.0 & 118 \\
\hline $10+12$ & 197 & 59.0 & 72 & 21.6 & 49 & 14.7 & 16 & 4.8 & 334 \\
\hline Total & 494 & 51.5 & 264 & 27.5 & 90 & 9.4 & 111 & 11.6 & 959 \\
\hline
\end{tabular}

Source: See Table I.

Iguape's social ladder, pretos were the least likely of any racial group to form legal unions. A high proportion of free adults either could not afford the high ecclesiastical fees for legal marriage or found other family strategies more attractive.

Occupational class too played an important role in determining the likelihood of household heads selecting legal or consensual unions. Table 3 records the marital status of Iguape's heads of household by HISCLASS. For this calculation, I first divided households according to whether or not their members formed a legally married family. I then further examined the details recorded about unmarried heads' relationship with other members of their households, and separated them into cases presenting evidence of current consensual unions, single parents living with their children, and unmarried people showing no evidence of current sexual relationships. ${ }^{\mathrm{I} 2}$

Not surprisingly, a slightly higher percentage (5I.5 per cent) of Iguape's household heads had been married than the general population. The formation of a sexual partnership - whether through legal marriage or a consensual union - frequently provided the impetus for young couples to found an independent household. In Iguape, it was not unusual for unmarried children to remain living with their parents well into adulthood. Household heads identifiable as involved in consensual unions represented a further 9.4 per cent of households; slightly more numerous (I I.6 per cent) were households like that of the freed preta slave Rita Delfina, 
comprised of single parents and their children. Nearly all of these families (96.I per cent) were headed by the mother rather than the father.

One of the limitations of censuses is that they give a picture of a community at an isolated moment in time, rather than reflecting the more dynamic long-term interactions between members. If anything, my calculations probably under-report the number of household heads involved in extramarital sexual relationships, as the absence of offspring or a live-in sexual partner does not provide conclusive evidence of celibacy. ${ }^{13}$ If households headed by individuals involved in current consensual unions and single parents are combined, a minimum of $2 \mathrm{I}$ per cent of Iguape's household heads engaged in sexual relationships outside marriage.

Table 3 further suggests a correlation between the decision to contract legal marriage and social class. Sugar-mill owners and heads of plantations had a higher marriage rate than lower-class household heads. Correspondingly, farm workers and lower skilled workers presented more evidence of consensual unions. The majority of heads in the lower-skilled worker category (HISCLASS 9) were women identified as spinners, seamstresses, and washerwomen - single mothers working in acceptable feminized occupations to support their children. Nearly 95 per cent of these single mothers were free women of color, placed at the bottom of the social hierarchy by the compounded liabilities of their race and sex.

Iguape's manuscript census permits another interesting insight into partner selection. Table 4 overleaf examines the racial endogamy among couples with both members present in a household. Henry Koster, an Englishman who ran a sugar plantation in the $\mathrm{I} 8 \mathrm{Ios}$, remarked that although "Brazilians of high birth and large property do not like to intermarry with persons whose mixture of blood is very apparent", marriages between branco men and parda women were fairly common. Neighbors only gossiped when "the person is a planter of any importance, and the woman is decidedly of dark color, for even a considerable tinge will pass for white". ${ }^{\text {I4 }}$ Still, the Iguape household census implied that race was a fundamental consideration when selecting a spouse. Among HISCLASS I +2 formal marriages were fully endogamous. Even members of the lower echelons of Iguape society overwhelmingly contracted marriage with members of the same racial groups. In no social class did racially exogamous partnerships represent more than 8 per cent of formal marriages.

In contrast, the composition of consensual couples suggests that sexual boundaries were not nearly so rigid outside the bonds of legal marriage;

I3. Katia M. de Queirós Mattoso, "Slave, Free, and Freed Family Structures in NineteenthCentury Salvador, Bahia", Luso-Brazilian Review, 25 (1988), pp. 69-84. Mattoso calculated that 53 per cent of free couples in 1855 Salvador were living in consensual unions.

14. Koster, Travels in Brazil, p. I75. 
Table 4. Head of household partner selection by HISCLASS, Santiago do Iguape I 835

\begin{tabular}{|c|c|c|c|c|c|c|c|}
\hline \multirow[t]{2}{*}{ HISCLASS } & \multicolumn{3}{|c|}{ Legal marriages } & \multicolumn{3}{|c|}{ Consensual unions } & \multirow[t]{2}{*}{ Total } \\
\hline & $\begin{array}{l}\text { Same } \\
\text { race }\end{array}$ & $\begin{array}{l}\text { Different } \\
\text { races }\end{array}$ & $\begin{array}{c}\% \\
\text { racially } \\
\text { endogamous }\end{array}$ & $\begin{array}{l}\text { Same } \\
\text { race }\end{array}$ & $\begin{array}{l}\text { Different } \\
\text { races }\end{array}$ & $\begin{array}{c}\% \\
\text { racially } \\
\text { endogamous }\end{array}$ & \\
\hline $1+2$ & 10 & 0 & 100.0 & 2 & 1 & 66.7 & 13 \\
\hline $3+4+5$ & 30 & 2 & 93.8 & 4 & 3 & 57.1 & 39 \\
\hline $6+7$ & 41 & 1 & 97.6 & 7 & 5 & 58.3 & 54 \\
\hline 8 & 32 & 1 & 97.0 & 2 & 6 & 25.0 & 41 \\
\hline 9 & 27 & 1 & 96.4 & 5 & 1 & 83.3 & 34 \\
\hline 11 & 12 & 1 & 92.3 & 3 & 2 & 60.0 & 18 \\
\hline $10+12$ & 145 & 9 & 94.2 & 37 & 12 & 75.5 & 203 \\
\hline Total & 297 & 15 & 95.2 & 60 & 30 & 66.7 & 402 \\
\hline
\end{tabular}

Source: See Table I.

Note: Includes only couples with both members present.

fully one-third of all co-resident consensual relationship occurred between members of different racial groups. Across the boundaries of class, individuals employed different criteria in selecting partners for formal versus consensual partnerships. This finding in many ways explains the historical paradox raised by the high incidence of consensual unions despite a widespread contemporary discourse emphasizing the value of legal marriage: legal marriage was reserved primarily for unions regarded as desirable and socially respectable. In a society where race was a crucial part of assigning social status, it is not surprising that most legally married couples - and especially those of sugar plantation owners - were racially endogamous.

\section{SLAVE PARTNER SELECTION}

As early as I7I9 the Brazilian prelacy affirmed the desirability of legal marriage for slaves. Church doctrine permitted Catholic slaves to marry other slaves or free people, admonished slaveholders not to impede slave marriages or separate married enslaved couples. ${ }^{\text {Is }}$ Questions concerning legal marriage between enslaved individuals were always polemic because they involved disputes over the individual rights of slaves as Catholic communicants and the property rights of slaveholders. Married enslaved couples enjoyed religious rights that limited their masters' power to sell 
them in times of economic hardship, or even to split them up during an estate settlement. Married slaves facing separation could appeal to local clergy to intervene on their behalf.

Carlos Augusto Taunay, author of an influential Brazilian agricultural manual, typified slaveholders' ambiguous view of legal marriages for slaves in his discussion of encouraging reproduction by enslaved couples: "Should the unions be legitimate or transitory? Religion and good order ask that they be legitimate, but on the other hand, it seems unjust and harsh to impose a new captivity on the slaves, and especially on the women, who find themselves with two masters" ${ }^{16}$ Although Tuanay's characterization of legal marriage as a form of servitude for women was revealing, his attitude against marriage for slaves was not so much benevolent as selfserving. Slaveholders sought to use legal marriage between their slaves to their personal advantage, encouraging it in some cases, as a way to foster reproduction of their labor force or reward amenable individuals, and discouraging it when the additional protections legal marriage offered enslaved families came into conflict with owners' desires to maximize their financial flexibility. Enslaved couples and families not united by legal marriage were even more vulnerable to separation through sale or testamentary bequest.

Information about nineteenth-century slave family formation, whether through formal marriage or consensual unions, is sporadic at best, but several excellent recent works have risen to the challenge. ${ }^{17}$ In I 835 , more than half the slaves living in Iguape were African-born. The grueling labor demands of sugar resulted in a very high slave mortality rate, fueling the demand for a constant stream of African slave imports. ${ }^{18}$ The high predominance of men among slaves imported from Africa reinforced the obstacles placed in the way of natural increase; a slave sex ratio of 146 meant that men far outnumbered women among potential enslaved mates. Only after the effective cessation of the Atlantic trade in 1850 did the enslaved sex ratio on regional sugar plantations become more balanced. By

16. Carlos Augusto Taunay, Manual do agricultor brasileiro (São Paulo, 200 I [1830]), 78.

17. Recent works on slave families in Brazil include Robert Slenes, Na senzala, uma flor: esperanças e recordações na formação da família escrava (Rio de Janeiro, I999); Isabel Cristina Ferreira dos Reis, Histórias de vida familiar e afetiva de escravos na Babia do século XIX (Salvador, 200I); Anna Gicelle García Alaniz, Ingênuos e libertos: estratégias de sobrevivência familiar em épocas de transição, I87I-I895 (Campinas, São Paulo, I 997); and Tarcísio Rodrigues Botelho, "Famílias e escravarias: demografia e família escrava no norte de Minas Gerais no século XIX", População e família, I (1998), pp. 2 I I-234. For a detailed study of a slave woman who eschewed marriage despite her owner's initial insistence, see Sandra Lauderdale Graham, Caetana Says No (Cambridge, 2002).

i8. See for example Michael Tadman, "The Demographic Cost of Sugar: Debates on Slave Societies and Natural Increase in the Americas", American Historical Review, 105 (2000), pp. I $534-$ I 575 . 
I 872, the enslaved sex ratio was I32, and only 5 per cent of the sugar recôncavo's slaves were of African birth. ${ }^{19}$

The I 835 census identifies 84 married slave women and 16 widows. Only 43 per cent of female slaves were African born, but they represented 72 per cent of the ever-married slave women, suggesting that the African women were more likely to contract marriage. This over-representation of Africans held for the ever-married male slaves as well; 86.7 per cent of ever-married men were African versus 60.I per cent of all enslaved men. This higher marriage rate was even more striking considering the greater obstacles facing prospective African spouses. Priests verbally examined slaves on Catholic doctrine before they could marry. Although some slaves may have been exposed to Christianity in Africa, participation in the church ceremony would further require proficiency in Portuguese.

Unfortunately, the census does not provide detailed information about these enslaved Africans' ethnic identities; nearly all are identified merely as "da Costa" - "from the coast" of Africa, a label that served more to differentiate them from Brazilian-born slaves than to provide real information about their place of origin. Still, whether they were born in Africa or Brazil, most slaves chose marriage partners who shared their birthplace. The census identified 47 slave couples, 44 (93.6 per cent) of whom married partners sharing their national origin. The parish records recording each marriage celebrated in Iguape supported this preference for marital partners with the same region of origin: of 97 slave marriages sampled between I 800 and I 885 , nearly 80 per cent were between spouses with the same place of birth. ${ }^{20}$

The economic status of their owners further influenced slaves' chances of contracting formal marriage. As Table s demonstrates, although the percentage of ever-married slaves did not uniformly increase with the size of holding, slaves living on extensive sugar plantations experienced the highest marriage rates. In I 835 , only i I.5 per cent of the adult slaves on Iguape's largest sugar plantations had ever married. Nevertheless, the marriage rate was even lower for slaves living on Iguape's smallest holdings: 2.4 per cent. In a society where slaveholders were reluctant to make any concessions that might diminish their control over their slaves, slaves on large plantations could select from a larger pool of potential mates. Slaveholders feared that cross-plantation marriages encouraged absenteeism and flight, as well as concentrating the economic benefit from any future enslaved children in the hands of the holder of the female slave. The parish marriage records I sampled found no marriages between slaves held by different owners. ${ }^{21}$

I9. See Table 6.

20. FHC, Livros de matrimonios, Santiago do Iguape, I774-I805; I806-1857; 1857-1902. Sample of every five years from I $800-1885 ;$ i 820 and I 825 could not be found.

21. Ibid. 
Table 5. Distribution of ever-married slaves by size of slave holding, Santiago do Iguape 1835

\begin{tabular}{lccc}
\hline $\begin{array}{l}\text { Holding size } \\
\text { adults } \& \\
\text { children) }\end{array}$ & $\begin{array}{c}\text { Number of ever- } \\
\text { married slaves }\end{array}$ & $\begin{array}{c}\text { Number of adult slaves } \\
\text { on this size holding }\end{array}$ & $\begin{array}{c}\% \text { adult slaves ever- } \\
\text { married on this size } \\
\text { holding }\end{array}$ \\
\hline 20 or less & 15 & 626 & 2.4 \\
$21-50$ & 34 & 449 & 7.6 \\
$51-100$ & 23 & 396 & 5.8 \\
$101-200$ & 31 & 720 & 4.3 \\
$200+$ & 102 & 884 & 11.5 \\
\hline Total & 205 & 3,075 & 6.7 \\
\hline
\end{tabular}

Source: See Table I.

Note: Adult slaves defined as individuals aged fifteen and older; holding size is the number of slaves held within each household.

A low incidence of cross-plantation marriages seems to have characterized Brazilian slavery; Alida Metcalf's research on coffee plantations in Santana de Parnaíba and Linda Wimmer's on Bahian tobacco regions also suggest that slaveholders opposed these marriages whenever possible. In contrast, Emily West's study of antebellum South Carolina found that one-third of slave marriages were between spouses living on different plantations. The rates of cross-plantation marriages on the sugar plantations of the British Caribbean were also considerably higher than those found in Brazil. Historian B.W. Higman calculates that in St Kitts and Jamaica, nearly 30 per cent of slave marriages were cross-plantation. In Barbados, the rate was nearly one-half. Only on the isolated plantations of Dominica were the cross-plantation marriage rates anywhere close to those found in Brazil: no more than 6 per cent of Dominican slave marriages crossed plantation boundaries. ${ }^{22}$

Iguape's low rate of formal slave marriages did not signal the absence of family formation or affective ties within the enslaved community. Slaves

22. Alida Metcalf's study of a coffee plantation in Santana de Parnaíba Brazil in I 820 found that 94 per cent of slave marriages occurred between two slaves owned by the same master; Metcalf, "Searching for the Slave Family in Colonial Brazil: A Reconstruction from São Paulo", Journal of Family History, I6 (I99I), pp. 283-297. Linda Wimmer's study of tobacco cultivation in eighteenth-century Bahia found 98 per cent of slave marriages between slaves held by the same owner; Wimmer, "Ethnicity and Family Formation among Slaves on Tobacco Farms in the Bahian Recôncavo, I698-1820", in José C. Curto and Paul E. Lovejoy (eds), Enslaving Connections: Changing Cultures of Africa and Brazil during the Era of Slavery (Amherst, NY, 2004), pp. I49-I62. Also, Emily West, "The Debate on the Strength of Slave Families: South Carolina and the Importance of Cross-Plantation Marriages", Journal of American Studies, 33 (1999), pp. 221-24I; B.W. Higman, Slave Populations of the British Caribbean, I807-I834 (Baltimore, MD, I984), p. 370. 
Table 6. Ever-married adults by race, civil status, and sex in selected sugar parishes, Babia I 872

\begin{tabular}{|c|c|c|c|c|c|}
\hline & \multirow{2}{*}{$\begin{array}{c}\text { Sex } \\
\text { ratio }\end{array}$} & \multicolumn{2}{|c|}{ Men } & \multicolumn{2}{|c|}{ Women } \\
\hline & & $\mathrm{N}$ & $\begin{array}{l}\% \text { ever } \\
\text { married }\end{array}$ & $\mathrm{N}$ & $\begin{array}{l}\% \text { ever } \\
\text { married }\end{array}$ \\
\hline Free branco & 121 & 8,661 & 42.7 & 7,171 & 47.5 \\
\hline Free/freed pardo & 115 & 10,357 & 49.7 & 8,986 & 51.7 \\
\hline Free/freed preto & 113 & 6,115 & 46.5 & 5,431 & 35.7 \\
\hline Free caboclo & 166 & 1,190 & 41.4 & 719 & 57.4 \\
\hline Total free & 118 & 26,323 & 46.3 & 22,307 & 46.6 \\
\hline Enslaved pardo & 132 & 1,276 & 40.2 & 964 & 57.5 \\
\hline Enslaved preto & 132 & 2,369 & 43.6 & 1,794 & 41.6 \\
\hline Total enslaved & 132 & 3,645 & 42.4 & 2,758 & 47.2 \\
\hline
\end{tabular}

Source: Brazil, Directoria Geral de Estatística, Recenseamento da população do Imperio do Brazil a que se procedeu no dia I ${ }^{\circ}$ de agosto de 1872 (Rio de Janeiro: I 873 ). The sample includes the sugar parishes of N.S. da Purificação, S. Pedro do Rio Fundo, N.S. do Oliveira, and S. Domingos in Santo Amaro; S. Gonçalo, Sant'Anna do Catú, N.S. do Monte, S. Sebastião, and N.S. do Soccoro in São Francisco do Conde; and Santiago do Iguape in Cachoeira.

Note: Adult defined as age sixteen or older; caboclo referred to individuals of mixed branco and Brazilian-Indian extraction.

who sought official sanction for their unions faced even greater impediments than impoverished free people. While ecclesiastical law stated that masters could not impede slave marriages, Iguape's parish records often included statements of owners' acquiescence, suggesting that their consent was a de facto requirement. Formal slave marriages represent a testimony to desirability of such unions, even in the face of extreme difficulty.

\section{CHANGES OVER THE NINETEENTH CENTURY}

The I 872 national census represented the next large-scale survey of Santiago do Iguape's population. Immediately striking was the dramatic decline in the absolute number, as well as the representation within the general population, of slaves. Over the course of thirty-seven years, Iguape's enslaved population fell from the absolute majority to less than one-third of the population. The end of the Atlantic trade had made its mark on the demographic composition of Brazil's sugar regions.

Table 6 presents the sex ratio, number, and percentage of adults in Bahia's sugar parishes identified in the 1872 census as ever married by sex, race, and legal status. Men significantly outnumbered women among both the free and enslaved populations. Still, 46.3 per cent of free men and 42.4 


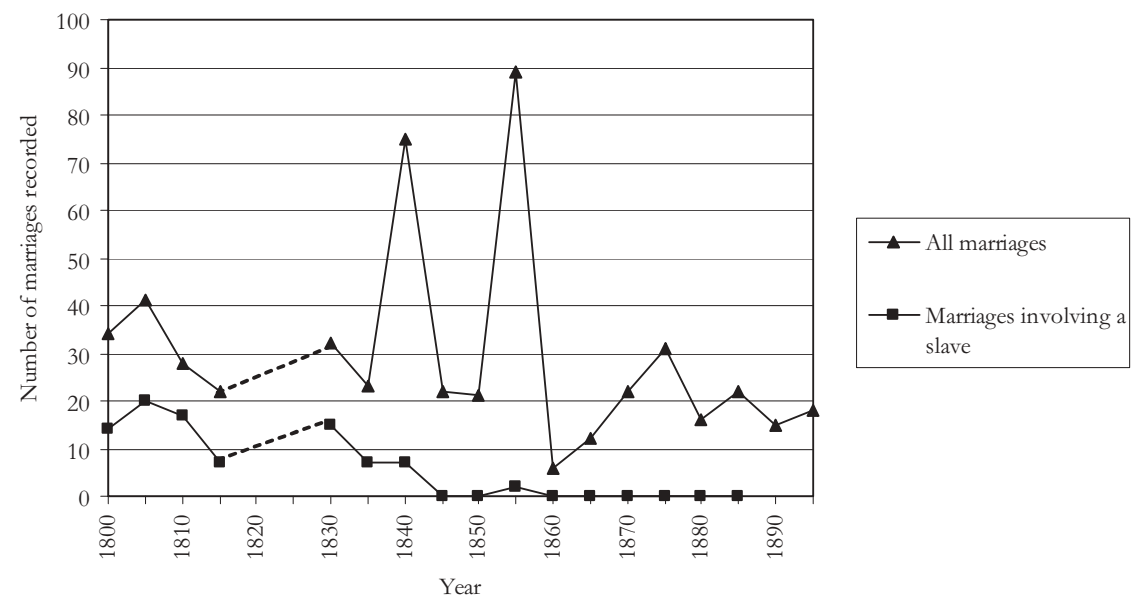

Figure 2. Annual number of marriages in five-year increments, Santiago do Iguape, I800-1895. Source: FHC, Livros de matrimonios, Santiago do Iguape, I774-1805; I806-I857; 1857-1902. Note: Records for 1820 and 1825 could not be located.

per cent of enslaved men were identified as married or widowed. These numbers imply that while the marriage rate reported for free men remained about the same as in 1835 (when it was 45.5 per cent), the number of enslaved men classified as married or widowers rose dramatically from 5.6 per cent to 42.4 per cent. ${ }^{23}$ If accurate, this would seem to suggest a remarkable change in slaveholders' willingness to permit their slaves to contract marriage and/or a greater estimation placed on legal marriage among Bahia's enslaved communities. However, the information recorded in Iguape's parish marriage records suggested an alternative explanation.

Figure 2 shows a slight decline in the annual number of marriages performed in nineteenth-century Iguape, with the exclusion of two large peaks mid-century. The year with the highest number of formal marriages was I 855 . Significantly, this was the year a cholera epidemic ravaged the bay area, killing nearly 17,000 in the surrounding countryside. As the epidemic progressed, priests dispensed with the publication of marriage banns, allowing consensual couples to formalize their unions, and protect

23. I decided to use a sample from several nearby sugar parishes because the 1872 figures provided for Santiago do Iguape seem unreliable. For example, in the printed census for Iguape, the number of ever-married branco men was higher than the entire adult male branco population. It seems very unlikely that every branco man over age sixteen in the parish, as well as some even younger men, had legally married. Men rarely married before their mid-twenties. Second, Iguape's number of free ever-married $(1,578)$ men outnumbered the free ever-married women (728) by more than two to one. 
their immortal souls, without delay. Couples who had lived together for years, forming households and raising children, rushed to seek religious sanction of their unions in a time of crisis. The devastation of the epidemic was overwhelming; even in the I 872 census, Iguape had not recovered its I 835 population. Historian Johildo Lopes de Athayde found a parallel surge in marriage rates in Salvador, the nearby provincial capital. ${ }^{24}$ Still, this mid-century surge in formal marriages appears to have been shortlived. The annual marriage rate for the final decade of the century was dramatically lower than that reported in the first.

The bottom line of Figure 2 represents the number of formal slave marriages each year. Despite the injunctions of local planters that "it is of absolute necessity that Masters, by some reward and other obvious and simple means, stimulate and invite slaves to marry", to preserve the region's labor force after the closure of the international slave trade in I 850 , the number of formal slave marriages recorded instead declined, and ended completely after I $860 .{ }^{25}$ Iguape's parish records suggest a greater slave reliance on informal unions over the course of the century, even in the face of greater sex-ratio equilibrium. This information contradicts the I 872 census's report that slave marriages increased. It seems probable that either the slave marriages reported in the census were not officiated and recorded in the same manner as those of free couples, or that the census estimates counted slaves living in consensual unions as effectively married. This explanation is further supported by historian Sheila de Castro Faria's findings that formal marriages among enslaved partners declined sharply after I 830 throughout Brazil. ${ }^{26}$ Unfortunately, Iguape's parish records for the second half of the century did not include the race or legal condition of spouses, so it is impossible to assess the impact of abolition in I 888 on formal marriage strategies among former slaves.

Information about the contractants' ages was only recorded for I 88 5 and 1890 . At the end of the century, the average age at marriage for women in Iguape was 26.I with a median of 22; men averaged 30.7, with a median of 28. Grooms were an average of 4.3 years older than their brides. Spousal age differences thus contracted from an average of 7.9 years in 1835 . The greater emphasis on mutual attraction between the young people involved, in contrast to pairings based entirely on men's economic prowess and women's sexual honor, contributed to a reduced age divide.

24. Johildo Lopes de Athayde, "La ville de Salvador au XIXe siècle" (Ph.D., Université de Paris X Nanterre, I975), p. 252. On the cholera epidemic, see Donald B. Cooper, "The New "Black Death': Cholera in Brazil, I $855-56$ ", Social Science History, Io (1986), pp. 467-488.

25. Miguel Calmon du Pin e Almeida, Ensaio sobre o fabrico do açúcar (Salvador, 2002 [I 834]), p. 60.

26. Sheila de Castro Faria, "Família escrava e legitimidade: estratégias de preservação da autonomia", Estudos afro-asiáticos, 23 (1992), pp. I I3-I3 I. 
The I 885 and I 890 parish records also provided details about twentynine couples' occupations. Not surprisingly in Iguape's plantation society, half of the men were farmers, and the remainder artisans, fishermen, and sailors. Only a handful of grooms were obviously elite: two businessmen and a man with a university degree. The difficulty of discerning a bride's class without information about her father's occupation makes suggestions about class homogamy unreliable; however, slightly more than half of the brides were identified as "domestics" - in this case, suggesting that the bride did not work outside her family home. Feminine reclusion remained an attractive characteristic for potential formal unions.

\section{CONCLUSION}

Writing in 1836 , George Gardner observed that "marriage is less common in Brazil than in Europe", and credited the predominance of nonsacramental unions with "the greater laxity of morals which exists here among both sexes". ${ }^{27}$ Formal marriage may have been less common in Brazil than in Gardner's native Great Britain, but his characterization of Brazilians as morally lax missed the point. Instead, Brazilians' choices to form alternative family and household arrangements were less proof of immorality than a reflection of different sets of community standards governing sexual relationships and partner selection. Formal marriage was not essential, but could be desirable under some circumstances. The dictates of race, class, and gender informed if and how Brazilians formally married.

In Iguape, consensual unions remained extremely common throughout the course of the nineteenth century. The trouble and expense of formal marriage contributed to its relative scarcity, along with the appealing flexibility of serial relationships. On the other hand, formal marriage conferred a greater degree of economic stability and social benefits. For members of the local elite, the social prestige of marriage and the formation of legitimate families outweighed the costs.

27. Gardener, Travels in the Interior of Brazil, p. I4. 